\title{
Someter por las armas, vigilar por la cámara: Estado y visualidad en el Chaco indígena
}

\author{
Mariana Giordano \\ Doctora en Historia \\ Investigadora de la Universidad Nacional del Nordeste \\ marianalgiordano@gmail.com
}

\begin{abstract}
Resumen Los modos de construir la visualidad en el Chaco argentino siguieron estrategias diversas sustentadas en una microfísica del poder. Si bien ellas no emanan únicamente del Estado nacional, fue desde la planificación de acciones y representaciones estatales que influyeron en la construcción de la tensión, control y coerción sobre las comunidades indígenas. Nos proponemos analizar la manera en que la visualidad se presenta como una experiencia que articula la visión con las prácticas culturales, sociales y políticas particulares. A partir del análisis de diversas estrategias de (re)presentación en las fotografías del indígena chaqueño, se indaga sobre su rol como prueba, verdad y orden en el proceso de sometimiento, vigilancia, y normalización, evidenciando la complejidad del entramado de poder y visualidad que, en diferentes capas/estratos y usos/circulación se manifestaron históricamente.
\end{abstract}

Palabras clave: Estado; visualidad; fotografía; Chaco indígena; sometimiento.

\section{Introducción}

$\mathrm{E}$ L AÑo DE i884 MARCó Un MOMENTO Significativo en la ocupación del espacio chaqueño, región considerada por el Estado argentino como la "última frontera" con el indígena.

La gran campaña militar sobre este territorio fue realizada en este año, precedida por avanzadas previas que se realizaron desde $1870^{1}$. Y continuada por "campañas de pacificación" que se prolongarán hasta 1911-12, mientras Estanislao Zeballos "soñaba con los indios del Chaco". ${ }^{2}$ Así, el Chaco se constituyó en la última región de la Argentina "ganada" al indígena por el Estado Nacional e implicó la configuración de un nuevo espacio social y productivo, a la vez que un episodio más del sometimiento indígena. Espacio ocupado ancestralmente por diversos pueblos originarios que a fines del XIX se encontraban en lo que constituyeron los Territorios Nacionales ${ }^{3}$ : para el caso del Terri-

1. Si bien la "gran campaña" de 1884 no tuvo los resultados que el Estado nacional esperaba los que se fueron logrando en las campañas posteriores (tanto la de 1899 como la de 1911), su importancia radica en la expansión de la frontera que la misma implicó, en el establecimiento de la línea de fortines y en la dispersión y relocalización de los grupos indígenas.

2. Nos referimos al texto de Estanislao Zeballos "Soñando con los indios del Chaco", basado en su experiencia de viaje realizada en 1916. Que forma parte de la literatura arquetípica de un representante de la generación del ochenta en la Argentina, respaldando desde el escudo del Instituto Geográfico Argentino al que pertenecía su autor, el papel del Estado y de las Misiones religiosas en las entradas al Chaco.

3. El Chaco Argentino fue organizado institucionalmente en dos Territorios Nacionales: Chaco y Formosa. 
torio Nacional del Chaco, eran las etnias mocovíes, tobas, wichís y vilelas. Además de la matanza de muchos de los líderes indígenas, las campañas militares produjeron una relocalización de las comunidades, su sedentarización y su progresivo acercamiento a los nacientes centros urbanos: en las zonas meridional y oriental de la región chaqueña, - las cuales fueron entregadas a los gobiernos civiles del Chaco y Formosa de forma paulatina -, se redujeron alrededor de 6000 indígenas y en 1911 se creó la Reducción civil de Napalpí en el Territorio Nacional del Chaco, y en Formosa la de Bartolomé de las Casas ${ }^{4}$. Ambos proyectos fueron por consiguiente, los que tuvieron la mayor atención por parte del Estado, y donde - desde la acción estatal - se produjo un gran proceso de cambio cultural de los pueblos originarios chaqueños y de explotación laboral esa mano de obra para la producción capitalista ${ }^{5}$.

El territorio "ganado" al "otro" fue progresivamente ocupado por un gran mosaico de inmigrantes (italianos, españoles, alemanes, polacos, ucranianos, checoeslovacos, croatas, servios, montenegrinos, húngaros, búlgaros, franceses, paraguayos), que iniciaron su ingreso en las últimas décadas del siglo XIX hasta la avanzada década de 1930 y que se sumaron a una población criolla estable - muchos de ellos procedentes de provincias vecinas -, que veía con recelos el ingreso masivo y la ocupación del espacio chaqueño de estos inmigrantes.

En este contexto, los modos de construir la visualidad en el Chaco indígena ${ }^{6}$ siguieron estrategias diversas sustentadas en una microfísica del poder en términos de Foucault (1993), las que no se resumen en una visualidad emanada únicamente por el Estado nacional, pero que sin embargo es desde la planificación de acciones y representaciones estatales que influyeron en la construcción de la tensión, control y coerción sobre las comunidades indígenas. Los discursos fotográficos apoyados en políticas e ideologías estatales procedentes de diversos campos institucionales influyeron en la mirada sobre los cuerpos, las sociedades y las culturas, y se convirtieron en instrumento de dominio. Al respecto, señala Tagg que " $\mathrm{La}$ fotografía como tal carece de identidad. Su posición como tecnología varía con las relaciones de poder que la impregnan. Su naturaleza como práctica depende de las instituciones y de los agentes que la definen y la ponen en marcha. Su función como modo de producción cultural está vinculada a unas condiciones de existencia definidas, y sus productos son significantes y legibles solamente dentro de usos específicos que se le dan" (Tagg, 2005, p. 85).

En tal sentido, nos proponemos analizar la manera en que la visualidad ${ }^{7}$ se presenta como una experiencia que articula la visión con las prácticas culturales, sociales y políticas particulares. A partir del análisis de diversas estrategias ${ }^{8}$ de (re)presentación de las imágenes del indígena chaqueño se investiga sobre su rol como prueba, verdad y orden en el proceso de sometimiento, vigilancia, y normalización ${ }^{9}$. Con ello se pone de manifiesto la utilización de la imagen como mecanismo de poder ${ }^{10}$ e instrumento en la construcción de identidades genéricas. En el análisis se toman como paquetes textuales fotografías que emanan de iniciativas o proyectos de instituciones y agentes hegemónicos que responden al Estado nacional y territoriano, o que, surgiendo de emisores procedentes de otros ámbitos - como el científico o comercial - se entienden en función de la acción y el poder estatal. Así, cada apartado de este artículo tratará imágenes/productores/estrategias de construcción visual del indígena chaqueño donde se articulan relaciones de poder con modos de ver, poniendo de manifiesto en su conjunto, la complejidad

\section{Sobre la creación de las reducciones véase Beck (1994).}

5. Véase, entre otros, Iñigo Carrera, 1984. Por otro lado, las misiones religiosas -tanto de franciscanos como de anglicanos- y el uso de la imagen en ellas, implicaron otra forma de aculturación que no se tomada en este trabajo. Véase al respecto Giordano (2006), Giordano y Méndez (2001).

6. Cabe señalar la sobrexhibición que tuvieron los grupos indígenas chaqueños con relación a otros espacios y grupos étnicos de la Argentina, comparable en parte con la difusión que a fines del siglo XIX y principios del siglo XX tuvieron los fueguinos. Sin embargo, la fotografía producida sobre los indígenas chaqueños se postergó temporalmente y se ha producido más canales de circulación.

7. Entendemos la visualidad siguiendo las propuestas de los estudios visuales de Mitchell, quien plantea que la cultura visual aborda el estudio de las prácticas sociales de la visualidad humana, en el que describe las relaciones específicas de la visión con las prácticas culturales particulares (Mitchell, 2003). Asimismo, Brea alude a los estudios culturales sobre lo artístico refiriéndose a aquellos que abordan la producción del significado cultural mediante la visualidad (Brea, 2005).

8. Siguiendo a Bourdieu, el concepto de "estrategias" se toma en tanto prácticas de acción no programadas que se encuentran entre la subjetividad y la objetividad, entre la racionalidad de los actores y la estructura. Y por lo tanto, contenida tanto del sujeto como de la costumbre e historicidad de la acción (Dewerpe, 1996).

9. Nos referimos a la normalización en lo que se refiere a los procesos socio-políticos que convergieron en la conformación del EstadoNación argentino a partir de estrategias que construyeran las identidades colectivas e individuales regulándolas por medio de un proceso de homogeneización.

10. Andermann ha abordado las formas de conocimiento y de registro del espacio geográfico desde la óptica del Estado a partir del estudio de la construcción de visualidades en la conformación de dos países latinoamericanos, Brasil y Argentina. Analiza como caso paradigmático la Campaña al Desierto sur en este último país (Andermann, 2007). 
del entramado de poder y visualidad que, en diferentes capas/estratos y usos/circulación se construyó y consolidó históricamente desde la colonialidad del poder (Quijano, 2004). En tal sentido, coincidimos con Tagg que "Al igual que el Estado, la cámara nunca es neutral. Las representaciones que produce están sumamente codificadas y el poder que ejerce nunca es su propio poder. Como medio de registro, llega a la escena investida con una autoridad especial para interrumpir, mostrar y transformar la vida cotidiana; con un poder para ver y registrar; un poder de vigilancia que provoca una completa inversión del eje político de la representación... No se trata del poder de la cámara, sino del poder de los aparatos del Estado local que hacen uso de ella, que garantiza la autoridad de las imágenes que construye para mostrarlas como prueba o para registrar una verdad" (Tagg, 2005, 85).

A la indagación en lo intra y extrafotográfico (aspectos ligados a lo estrictamente visual, a los modos de representación de situaciones, sujetos y escenarios) $)^{11}$, debe sumarse otro aspecto que constituye la otra cara de la visualidad: la invisibilidad. El poder del Estado se manifiesta no sólo en la obturación de la cámara, sino también en aquello que se oculta o invisibiliza, "lo visto y lo no visto" (Burke, 2001), que se complementa con el "hablar y callar": lo que no se muestra implica un recorte, un sesgo que supone toda toma fotográfica, pero también constituye una estrategia de plantar un (des)conocimiento. De ahí, que el análisis de los documentos visuales debe considerar tanto el recorte de lo que se ve, los olvidos y los ocultamientos, como las voces de los "otros" que fueron "objeto" de captura visual que pueden completar los recortes o los ocultamientos, estableciendo una grieta en los aparatos ideológicos del Estado, como modo de desentrañar, a partir de lo visto y lo no visto, los aspectos ocultos de las relaciones de poder. Es así que a partir de lo que el Estado calla u oculta analizaremos un corpus de imágenes que permite visibilizar la violencia desde una supuesta no violencia de la representación. Y las voces de los que fueron "objeto" de representación o sus descendientes surgen de contextos de recepción de las mismas por parte de las comunidades indígenas actuales ${ }^{12}$, instancias que se consideran en algunos casos de análisis y que permite una lectura dialógica desde la fotografía.

Las imágenes son en sí mismas conocimiento. Y ello no se debe a su objetividad, ni por ser "prueba" como se consideraba en la época en que fueron obtenidas y como lo asume gran parte del discurso histó- rico, sino porque constituyen ejemplares de una lógica visual de presencias y ausencias, de visibilidades y ocultamientos, de maneras de componer la imagen que invitaron/invitan al espectador - especializado o no - a un reto visual.

Esbozamos como hipótesis que el imaginario civilizatorio y la construcción de la nacionalidad afirmados desde poderes hegemónicos con relación al indígena chaqueño tuvo en la fotografía obtenida por agentes procedentes de diversos campos institucionales-estatales, un "artefacto-medio" para transmitir los objetivos estatales de sometimiento, en los que se establece una colonización de la mirada y una homogeneización del "otro" a partir de una premisa normalizadora: controles visuales y militares, fotografía y armas, dispararon de forma simultánea sobre el indígena chaqueño.

La fotografía no sólo era mostrada como documento irrefutable del triunfo de la "civilización" sobre la "barbarie" y un instrumento de control y vigilancia, sino también, un símbolo de posicionamiento sociocultural: no todos podían tener una cámara y no todos podían pagar una imagen por encargo, entre los que estaban los grupos indígenas, más aún cuando muchos de ellos no conocían una máquina fotográfica. Al decir de Edwards, la fotografía representaba la superioridad tecnológica subordinada a la delineación y control del mundo físico (Edwards, 1992,14), y en ese mundo físico se incorporaban a las poblaciones nativas. Así, la fotografía asume un control basado en la creencia de su verdad: ver e identificar se convierten en la fotografía antropométrica - o en aquella que presenta atisbos antropométricos -, en mecanismos de sometimiento y control de la población indígena chaqueña. La fotografía se introduce, por consiguiente, en paralelo a la ocupación militar del espacio chaqueño, y su supuesta verdad certificaba el "apacible" triunfo sobre el indígena, ya que se pone en marcha una estrategia que caracterizará la producción de imágenes oficiales sobre el indígena chaqueño: la invisibilidad del conflicto.

\section{Someter por las armas, vigilar por la cámara}

En forma contemporánea a las campañas militares al Chaco y con posterioridad a ellas, la vigilancia por medio de la línea de fortines y la presencia de tropas

11. Que pueden ser considerados en los contextos discursivos de la producción, circulación y recepción de las imágenes.

12. En tal sentido, una instancia de investigación dialógica con los grupos étnicos que actualmente habitan el Chaco - toba, wichi y mocoví ha sido una estrategia de investigación que no sólo articula nuestras lecturas de la imagen con las que proceden de las comunidades, sino que también permiten poner en relación la memoria visual con la oralidad que ha caracterizado la transmisión de memorias en estas comunidades (Giordano, 2010; Reyero, 2010). 
regulares se complementó con una vigilancia producida por la cámara: así como la fotografía fue la herramienta utilizada por diversas instituciones y sistemas de producción como control social-visual desde las últimas décadas del siglo XIX - tomemos como ejemplo la fábrica, el hospital, el manicomio, la escuela, etc.también se instrumentó su uso por la fuerza expedicionaria-militar y, como analizaremos más adelante, ocupó un rol relevante en las Reducciones civiles que el Estado implementó para los indígenas ${ }^{13}$.

Imaginemos el Chaco como una gran prisión, como la materialidad espacial y natural donde se produce esta relación entre sujetos y poderes, en la cual la fotografía busca validar o legitimar prácticas "benignas" para con los indígenas sometidos - indígenas "amigos" que simbolizan el "acuerdo pacífico" con el Estado -, y que también vigila a través de la lente la eficacia del control espacial.

La gran campaña militar al Chaco realizada en 1884 a cargo de Victorica estuvo acompañada por un fotógrafo, Luis Parrotta, cuyas imágenes se conservan unas pocas en condiciones de lectura debido al deterioro físico de otras. Una de ellas se convierte en la síntesis del sometimiento y control, tanto desde lo formal y gestual como del contenido: se trata de un conjunto de indígenas vestidos con uniformes militares que posan junto a militares del mismo ejército que los sometió. Dispuestos en tres planos, en el primero de ellos un grupo de indígenas lanceros permanece arrodillado; en el plano posterior, algunos portan fusiles y otros, instrumentos musicales de la banda militar. El plano medio concentra la mirada del espectador: nos encontramos con un militar montado a caballo ubicado en el centro de la composición e interponiéndose entre los dos planos mencionados anteriormente. Si bien podríamos hablar de las distintas significaciones que esta imagen dispara, que podrían confluir en el "poder del centro"14 -tanto desde lo compositivo como desde lo perceptivo- la imagen se convierte en sustento de la premisa de la que partimos: someter y vigilar, por lo que nos interesa abordarla especialmente desde la construcción de la mirada. El fotógrafo construye los planos compositivos mencionados, y organiza una escena donde la mirada recorre las líneas de formación para depositarse finalmente en el centro; esos elementos los presumimos cuando miramos esta imagen, pero si nos exponemos a una experiencia de la visión (Mitchell,
2003, 33-39), nos encontramos con una irrealidad de la imagen, una desaparición de lo real o de la sustancia en cuanto referencia, un "testigo" desaparecido. La significación de la imagen no se vincula solamente a presupuestos formales y temáticos, sino también en función de los modos en que se construye socialmente la mirada ${ }^{15}$, de lo que se hace visible y queda diluido en una nueva realidad, o de aquello que se invisibiliza. Esta imagen alude por lo tanto a una construcción de una mirada dominante donde lo que la sociedad presuponía como realidad, no lo es: el indígena chaqueño ya no es el salvaje indómito, el bárbaro antropófago del imaginario colonial y decimonónico, sino que es un "objeto" que ha perdido la sustancia, porque ha dejado de ser "sujeto", y es contemplado desde una mirada totalizadora y contemplativa, desde el ojo del panóptico. Al decir de Baudrillard (1998), cuando lo real ya no es lo que era, la nostalgia asume el significado. Sujeto y sustancia parecen haber desaparecido, porque lo real en cuanto referencial se muestra perdido o normalizado a través de la apropiación de un espacio históricamente aprehendido como inaccesible y el sometimiento de su población, que había sido "imaginarizada" históricamente como el "símbolo del demonio" (Trinchero, 2000).

Otro aspecto significativo y como lectura alternativa/complementaria al análisis previo con respecto a esta imagen, remite a la circulación actual de la misma y a las descripciones que la acompañan: en un libro titulado "Soldados 1848-1927" (Alexander y otros, 2001), que visualiza la labor expedicionariamilitar argentina, esta fotografía se describe de la siguiente manera: "Campaña al Chaco. 1885. Tropas al mando del comandante Astorga. Fracción de infantería. Formados en la línea con sus fusiles con bayoneta armada. Adelante. Indios amigos a los que se les ha regalado lanzas y prendas de uniforme en señal de amistad". Descripción que, centrada en el referente, actualiza el discurso histórico-militar y estatal sobre dicha campaña y la "amistad" con los indígenas: la construcción de la mirada no ocupa un lugar de importancia en este discurso, sino la verificación de un hecho que se busca, mediante la imagen y el texto, presentar como "prueba" y "verdad" (Tagg, 2005).

De hecho esta imagen también debe ser considerada con relación a otros instrumentos de dominio que refieren a una "tiranía del poder" ${ }^{16}$, ya que las

\section{Sobre los usos de la fotografía como medio de vigilancia (Tagg, 2005, p. 97-103).}

14. Aludimos al concepto de Arnheim sobre la organización del espacio compositivo a partir del eje central y la disposición simétrica de planos y figuras (Arnheim, 2001).

15. Incluso podríamos comparar esta imagen con pinturas de batallas o de rendiciones y parlamentos, mientras tanto alude al "se acabó" de la guerra y presenta "las partes" de la contienda en un escenario de "encuentro".

16. Mitchell señala, con respecto a la cuestión del "poder de las formas visuales" que "aunque no existe ninguna duda de que la cultura visual [...] puede ser un instrumento de dominio, no pienso que resulte productivo singularizar campos como el de la visualidad, las imágenes, el espectáculo o la vigilancia como los vehículos exclusivos de la tiranía política" (Mitchell, 2003, p. 33). 


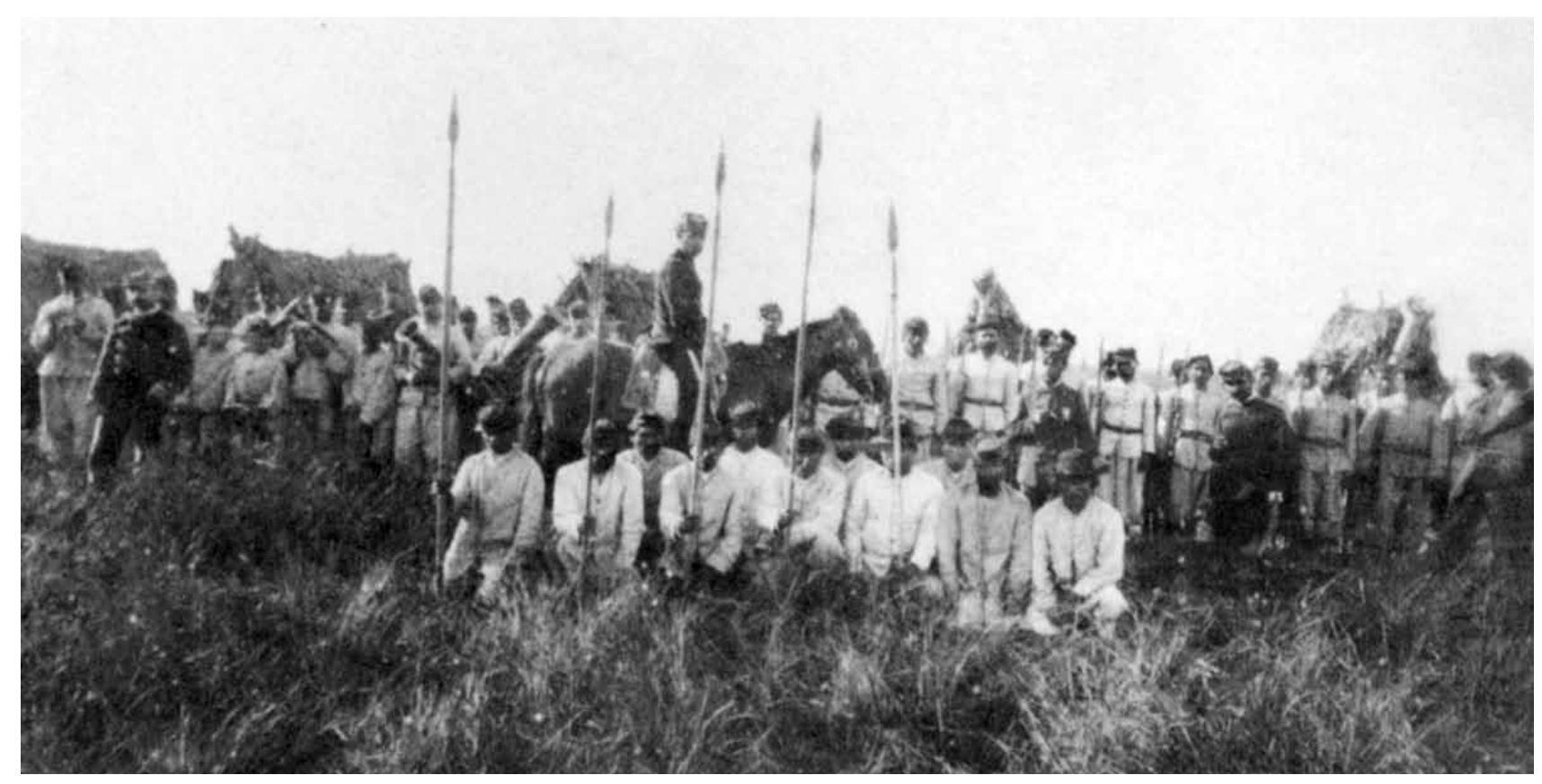

Imagen 1. Luis Parrotta. Expedición del general Benjamín Victorica. Ca. 1884-85

Archivo General de la Nación

armas, la cultura material, la palabra - articulada en la legislación, en decisiones gubernamentales, etc. - y la cultura oral - entre otras - coadyuvan en la construcción del "otro" y constituyen mecanismos articulados de esa tiranía.

Si bien la imagen de Parrotta es un símbolo del poder militar-estatal, otras fotografías emanadas de militares también se constituyen en referentes del sometimiento del indígena chaqueño: los castigos se invisibilizan y son las "escenas étnicas"17 en medio del "desierto"18 tomadas por militares que participaron en las Campañas al Chaco argentino, las que sobresalen. Las mismas sintetizan las "Campañas de pacificación”, últimas empresas militares que se prolongaron hasta 1911-12: el adjetivo "pacificación” impuesto por el Estado se corresponde con la referencia visual que se construyen en estas imágenes, incluidas algunas en escritos publicados con posterioridad a la experiencia militar de sus emisores. Se presenta al indígena a partir de dos estrategias que podrían considerarse contrapuestas, pero que, sin embargo coadyuvan a transmitir el ambiente "pacifista" de las campañas militares: por un lado, como resabio de un mundo en extinción, semidesnudos, con arcos y flechas, mimetizados con el ambiente natural o viviendo en sus toldos, buscando la (re)aparición de elementos de la "sustancia" perdida en la imagen de Parrotta. Por otro, con vestimenta militar y participando en conjunto con expedicionarios militares en fogones. En cualquiera de los casos, situándonos en la referencialidad de la imagen, ha desaparecido el "problema indígena" que desde los inicios de la generación del ochenta se había convertido en uno de los ejes de la acción estatal argentina.

De tal forma, las imágenes del acuerdo sintetizan esta producción, a la vez que posicionan claramente la superioridad tecnológica que suponía el medio fotográfico como forma solapada de sometimiento visual-técnico sobre los grupos indígenas chaqueños sometidos también, por medio de las armas.

\section{Referencialidad e imagen del otro}

La territorialización que siguió a la ocupación del espacio chaqueño ${ }^{19}$ supuso un camino diferenciador referente a los grupos étnicos chaqueños a partir

17. Alvarado considera como "escenas étnicas" a aquellas imágenes donde sujetos y objetos entran en una dinámica de relaciones espaciales, por lo que genera una atmósfera no contaminada por la presencia de la cámara (Alvarado, 2001).

18. Sobre la construcción discursiva del concepto de "desierto chaqueño" véase Lois (1999).

19. La territorialización no alude solamente a la ocupación y al control del Estado sobre el territorio, sino al proceso de construcción social de un espacio, donde se deben considerar las relaciones de los agentes económicos y sociales con el entorno espacial y material (Santos, 1997). En el caso chaqueño la territorialización implicó la creación de poblados, la introducción de pobladores de provincias vecinas y de inmigrantes europeos, el tendido de líneas férreas y en el mundo indígena la creación de las últimas misiones religiosas en el espacio del Chaco argentino, colonias agrícolas y reducciones civiles. Las relaciones económicas y sociales que se construyen en este proceso se entienden en el cruce de estos elementos. Véase, entre otros, Iñigo Carrera (1984); Beck (1994); Gordillo (2006). 
de operaciones de desplazamientos espaciales, mientras se profundizaban procesos de homogenización mediante la "integración" del indígena al EstadoNación. La escolarización y la incorporación a los medios de producción capitalista regional, conjuntamente con la formalización de su "incorporación" al Estado por intermedio de la documentación, constituyeron actos formales y simbólicos homogeneizadores de la "integración" del indígena chaqueño como "ciudadano" 20 . Las reducciones pasaron a ser otra escala del panóptico, donde la vigilancia de la imagen se hace presente. Los observadores estatales que por distintas razones recorrieron la región, fueron artífices de dicha vigilancia.

Entre los diversos agentes que actuaron en el contexto de las campañas de pacificación en la primera década del siglo XX, - pero al margen de la acción militar -, un ejemplo significativo es la visualidad que hace del indígena chaqueño José Elías Niklison, inspector del Departamento Nacional del Trabajo ${ }^{21}$, quien obtuvo imágenes que fueron difundidas junto a textos del autor por la Revista Caras y Caretas (10/03/1917), La Revista del Mundo ${ }^{22}$ e insertas algunas de ellas en una reedición reciente de uno de sus informes ${ }^{23}$ que en su edición original no las contenía.

El imaginario de la mansedumbre fue nuclear en las imágenes difundidas por el propio autor, -aunque pudo no haber sido su objetivo explícito-, sin embargo en un análisis del conjunto de las imágenes, esta mansedumbre visibilizada se puede considerar como el primer paso en el proceso de homogenización a partir de la imagen: retratos de medio cuerpo donde los indígenas posan pasivamente con los brazos cruzados se mezclan con imágenes grupales costumbristas. Aquellas en las que el referente aludía al trabajo indígena - aspecto que Niklison evaluaba en su inspección - buscaban articular el discurso escrito con el visual: la imagen complementaba la palabra y se erigía en indicador del proceso de homogenización que se pretendía lograr con la población indígena, pero, particularmente sus denuncias desvelaban la explotación

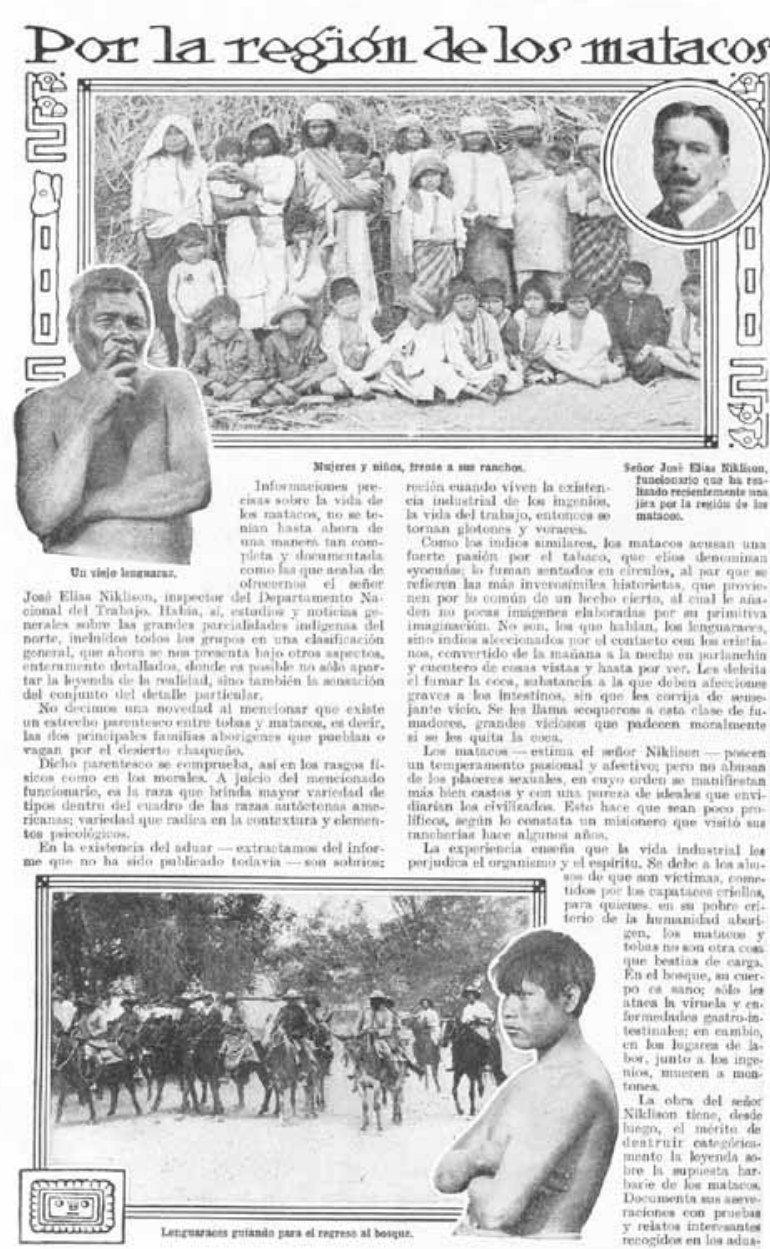

Imagen 2. Difusión de las investigaciones de Niklison en Caras y Caretas (Buenos Aires), 10 de marzo 1917

del cual era objeto el indígena trabajador, aspecto en el que la palabra se manifiesta con mayor énfasis que la imagen.

También interesa considerar en este caso los canales de circulación de las imágenes: un amplio público de Buenos Aires y ciudades del interior donde se difundían revistas como Caras y Caretas y dentro de la estructura estatal, los funcionarios que accedían

20. Cabe señalar que "nacionalizar" implicó invisibilizar, suprimir las particularidades culturales, religiosas. Y que estas estrategias se dieron en el contexto de un fuerte discurso nacionalista, donde la omnipresente mirada hacia Europa. Véase, entre otros, Altamirano y Sarlo (1983); Scarzanella (2003); Segato (2007). Si bien el discurso escrito como modo legitimador de la construcción Estado-Nación ha sido abordado en numerosos trabajos, no así el discurso visual. Véase Briones y Lenton (1997). Sobre el uso de la imagen - tanto pictórica como fotográfica y fílmica -, en la búsqueda y construcción de una identidad en la Argentina, véase Amigo (1999); Muñoz (1995).

21. Niklison "compartía la opinión de un núcleo de pensadores y funcionarios progresistas vinculados con el mundo laboral, cuyas ideas partían del principio que ante el inevitable avance de la República sobre los antiguos territorios indios, el aborigen debía irse incorporando lentamente a todos los aspectos de la vida del país, comenzando por la faz laboral, pero bajo el estricto contralor del Estado, responsable de su sometimiento" (Lagos, 1989).

22. Bajo el título "Los indígenas del Norte en la Argentina - apuntes de actualidad" Niklison difundía parte de su trabajo realizado en el Norte argentino (Niklison, 1919).

23. Sus informes fueron originalmente publicados en el Boletín del Departamento Nacional del Trabajo: en 1916 publicó parte del informe presentado al Departamento del Trabajo bajo el título "Los tobas", luego "Investigación en los territorios federales del Chaco y Formosa" y en 1917 "Investigación sobre los indios matacos trabajadores" (lo mismo es conocido como "Informe Niklison"). En la reedición de este último, se incorporaron imágenes que carecía de la edición original, pero que fueron facilitadas por la familia Niklison a los editores que se consideran en este análisis (Lagos, 1989). 
a los informes que incorporaban imágenes. Aquellas fotos que se han incluido en la reedición de Investigación sobre los indios matacos trabajadores - pero que no integraban la edición original ni fueron difundidas en forma contemporánea- articulan las imágenes del indígena trabajando en los cañaverales con escenas étnicas y retratos con poses impuestas. Desde lo formal, las imágenes presentes en las publicaciones periódicas mencionadas, como las conservadas en el archivo personal de Niklison e incluidas en ediciones posteriores, se sustentan en un interés documental desde un proyecto fotográfico pericial y objetivista, con un enfoque carente de la "profundidad del campo", haciendo que la focalización refuerce la chatura de la imagen ${ }^{24}$. Pero también algunas de estas imágenes fueron publicadas en formato postal, incluso una en que el mismo Niklison se incluye en la escena, enfatizando el "estar ahí" del observador positivista.

Salvajismo como sinónimo de pasado; trabajoproducción en alusión al presente; en cualquier caso un ideal normalizador - en contenido y forma sustenta a la imagen. Esta dualidad del antes-ahora se presenta como dos momentos que son uno - porque la fotografía actualiza esa vida pasada -, encuadrando aspectos de la vida cotidiana y de la explotación indígena en los establecimientos de caña de azúcar a los que alude en los escritos desde una postura más crítica que en la imagen.

La vida del trabajo, el indígena sometido y las escenas étnicas no fueron las únicas construcciones visuales que los agentes del Estado nacional afirmaran sobre el indígena chaqueño en las primeras décadas del siglo XX. Otras acciones como la jura de la bandera en las Reducciones civiles fueron también representaciones por medio de la fotografía. Los caciques de la Reducción de Napalpí primero, y luego los "colonos", mujeres y niños fueron capturados en imágenes por "especialistas" enviados por la Comisión Honoraria de Reducciones de Indio ${ }^{25}$ para "observar" la acción estatal en las reducciones. Sus informes aluden claramente a su trabajo de "observación", que la cámara captaba como modo de constatación de la "igualdad ante la ley", a la vez, enfatizando en el "orden" logrado por el Estado, en el que abandona la época de inseguridad, conflictividad y resistencia. Este corpus constituye uno de los más elocuentes en cuanto al principio de cons- trucción de ciudadanía e identidades por medio de la fotografía y de homogeneización de la población: un ícono de Napalpí fue la Cacica Dominga ${ }^{26}$, quien aparece en las mismas portando la bandera argentina y realizando la jura del símbolo patrio, mientras que en otras preside juramentos realizados por miembros de la comunidad de Napalpíi ${ }^{27}$.

Estos agentes del Estado, productores de imágenes en diversos contextos de la vida institucional nacional y del Territorio Nacional del Chaco, y en distintos contextos socio-históricos de la población indígena chaqueña, cumplen la función de "observadores": la lente de la cámara reemplaza metonímicamente el ojo humano y se logran imágenes cuya característica sobresaliente en la producción, uso histórico y contemporáneo radica en el "referencialismo" o en el principio de "transferencia de la realidad". Así, más allá de la subjetividad de la toma, estas imágenes fueron utilizadas en el dominio de la referencialidad, vinculadas al supuesto epistemológico de la mímesis fotográfica, así como de la huella única de "la realidad" del indígena chaqueño. La generalización del "otro" que el discurso visual ha promocionado - también el escrito en sus diversos emisores y sus estrategias e intereses - se sustentó en estos elementos que la imagen fotográfica sustentaba: verdad, similitud, autenticidad, espejo de "la realidad" indígena. No se planteaba el recorte, lo que quedaba afuera, el ilusionismo mimético, tampoco lo que conscientemente o no, se invisibilizaba.

\section{La imagen como estatuto normalizador: la foto-documento}

La identificación de la persona a partir de datos civiles y morfológicos, anexando luego la imagen fotográfica de frente y perfil sobre un fondo neutro se había comenzado a utilizar en los procedimientos policiales de identificación y en la práctica antropológica como herramienta visual de los estudios antropométricos; luego, el sistema se extendió a la identificación de toda la población ${ }^{28}$, en el contexto de un aumento significativo de la densidad iconográfica que la industria visual produjera desde la segunda mitad

\section{Sobre el rasgo de planitud y su relación con el enfoque (Dubois, 2008, p. 95-99)}

25. Los informes de Arturo Ameghino, Lorenzo Galíndez y Ramón Pardal sobre sus "observaciones" fueron publicados, junto a las imágenes obtenidas por Galíndez, por la Comisión Honoraria de Reducciones de Indios (1936).

26. Cacica mocoví que vivió los episodios de la Matanza de Napalpí de 1924, logró escapar y fue perseguida durante los meses siguientes a la misma. Las imágenes aludidas son de 1936.

27. Más adelante analizamos una instancia de recepción de estas imágenes por la comunidad de Colonia Aborigen-Napalpí.

28. Véase para el caso argentino Penhos (2005).Sobre el uso de la fotografía en los registros antropométricos de indígenas chaqueños, véase Giordano (2004b). Sobre la historia de los estudios antropológicos en el Gran Chaco, véase Gordillo (2006, p. 225-254). Debemos advertir que el rostro es entendido como un mapa geográfico, ya que los estudios antropométricos realizaban no sólo mediciones y descripciones de cada uno de los aspectos del rostro, sino que además, ellos se interpretan a partir de una síntesis que reduce esos elementos en la noción de "tipo". 
del siglo XIX. Ambas prácticas y usos de la fotografía - la identificadora-estatal y la científica - suponen una asociación entre diversos conceptos que el Estado y la ciencia manejaban en la misma época: progreso, verdad y orden, a los que la fotografía se aúna en función de ser un "instrumento del progreso" que sustenta un lenguaje "verdadero" y que a partir de su uso permitirá un "orden" institucional y una estricta "clasificación” en el campo científico.

Planteamos en este apartado la función de la foto-documento o foto-carnet como socialmente se la conoce, en la intención del Estado de incorporar a la población indígena chaqueña como "ciudadanos"; 29 pero a la vez, la influencia que la introducción de esta práctica tuvo en la construcción de una autoimagen, teniendo en cuenta que en la mayoría de los casos, fueron históricamente las primeras imágenes que tuvieron las comunidades indígenas y son en la actualidad, algunos de los pocos testimonios visuales que guardan de sí mismos o de sus antepasados.

La fotografía del documento supuso desde sus inicios la visibilidad de la identidad del retratado, que al Estado le permitía - junto a otras referencias escritas - sistematizar la información de los ciudadanos, ejerciendo de esta forma un mecanismo de control. Por ello la foto-documento debe entenderse, por una parte, en función de la importancia de la documentación individual y por otra, en su materialidad, individualidad y usos, independientemente del contexto del documento, donde el rostro busca sintetizar "la identidad" del retratado. Como expresa Gordillo, “... la documentación individual crea sujetos visibles y por ende más controlables, este proceso también puede incrementar el poder relativo de poblaciones subalternas al expandir sus derechos sociales y políticos" (Gordillo, 2006, p. 176); pero a la vez estas fotos se convirtieron históricamente en huellas "irrefutables" de su rostro y, desde la concepción occidental de la fotografía, de su identidad.

Es que, siguiendo los parámetros de la fotografía criminalística y de la fotografía antropométrica, la foto-carnet contiene gran parte de los elementos de esas prácticas; consideremos algunos de ellos teniendo en cuenta que el retratado es un "otro" en el concierto de la sociedad hegemónica-estatal de principios del siglo XX en el Chaco, cuando comienza a implementarse esta práctica: a) los rostros son "tipos" productos de un ideal generalizador, donde la identi- dad se da por los rasgos faciales, a los que acompaña la nominación -en castellano y no en la lengua originaria del retratado, mas allá que las culturas chaqueñas son ágrafas- b) responde a estrictos ángulos de toma; c) la neutralidad de los fondos y la administración pareja y uniforme de la luz, también contribuyen con una representación estereotipada.

Escolar plantea la impronta del fenotipo -que argumenta puede considerarse como "feno-mito"- en la construcción de "marcas racializadas" para el caso huarpe (Escolar, 2007); podríamos suponer que la fotografía del documento, que claramente sintetiza esos rasgos fenotípicos del individuo, se convierte en una afirmación visual para los distintos grupos sociales, pero que, en el caso de la población indígena chaqueña, ha sido la única imagen que durante décadas han poseído de sí mismos. ${ }^{30}$

Así, las fotografías obtenidas para los documentos personales -en principio, documentos de identidad, más tarde utilizadas en documentos de identificación laboral, de salud o de agremiación, entre otras,- son las que nos interesan particularmente, por su implicancia en la vida personal y en la imagen de sí mismos de los sujetos representados.

Gordillo señala que para el caso de los documentos de identidad, éstos se convirtieron para los indígenas chaqueños en "fetiches de ciudadanía" (Gordillo, 2006, p. 169-193): ello se enmarca en el valor de la palabra escrita en momentos de las campañas militares al Chaco y con posterioridad a las mismas, dado que los documentos escritos pasaban a subvertir el salvajismo al convertirlos en "argentinos". Por ello los documentos, que para el Estado constituían un elemento controlador de la burocracia, eran concebidos por los indígenas más allá de su valor simbólico, “...como objetos potentes que, por sí mismos, configuran el resultado de procesos sociales" (Gordillo, 2006, p. 171). En este fetichismo del documento, nos interesa analizar el valor atribuido a la foto del documento en el pasado y en la actualidad, donde la "foto carnet" actúa de imagen probatoria y legitimadora de identidad. El fuerte contenido biologicista y positivista que conlleva la fotografía de los documentos asimila los datos morfológicos con la identidad, y trasladado a la situación de los "nuevos ciudadanos" en que se transformaban los indígenas, el Estado les estaba "otorgando" identidad. Más allá del concepto de la fotografía como registro miméti-

29. Por ello, debe ser entendida desde las representaciones hegemónicas de la Nación, que buscaron la homogeneización social y cultural.

30. Si bien en el caso chaqueño, la adscripción identitaria que surgió de los comentarios de entrevistados que observaban fotografías históricas que les presentamos en instancias de recepción, también refuerzan el concepto de "la cara te dice todo", la cuestión de la lengua se convierte en el tópico principal de identificación por parte de los intragrupo. Raimundo nos decía: "Para ustedes yo soy indio, porque tengo cara de indio. Pero para mi gente no soy, porque no hablo la lengua. Yo me siento doblemente discriminado". Entrevista a Raimundo Barrientos. Colonia Aborigen, 11 de junio de 2007. Sobre la importancia del rostro en los procesos de autoidentificación de los indígenas chaqueños, véase Reyero (2009). 
co que permitía obtener del retrato la identidad del retratado - concepto que manejó la fotografía del siglo XIX y XX -, debe evaluarse su proyección y utilización en las comunidades indígenas chaqueñas. Estas en su mayoría nunca habían tenido una fotografía, a la vez que ese modelo de representación y ese artefacto fotográfico se apartaba de los propios; su presencia en la vida personal implicó un aspecto no menor en los procesos de construcción de hegemonía, y como contraparte, en los sentidos de pertenencia que estos grupos fueron diseñando, a partir de significados sobre la representación del rostro claramente hegemónicos.

Las implicaciones de la foto-documento en la construcción de identidad/es de los grupos indígenas tuvo varias aristas, pero en cuanto a los contextos de producción antes mencionados distinguimos las siguientes: para el Estado, supuso el registro visual de la identidad del indígena, a la vez que el documento en su conjunto - imagen y texto - era el testimonio de la "igualdad" de ciudadanos y el ejemplo más eficiente de la "imagen corporativa" de los Estados Nacionales. Pero es más clara esta afirmación al comprender el carácter reificador/testimonial que la foto tiene en los diversos documentos personales, muchos de ellos que nos han acercado en el trabajo de campo. La fotodocumento implicó un nuevo proceso de "captura" y sumisión a los presupuestos políticos-ideológicos de la hegemonía estatal y a los modos de representación hegemónicos que la práctica fotográfica encarnaba.

Para los antepasados, las fotos insertas en el documento, esos "papelitos" que le permitían tramitar, gestionar, ser "ciudadanos", testificaba y los hacía más "confiables" en el panorama político-social de la época, y la imagen fotográfica avalaba visualmente esa "confiabilidad": aquellos que miraban sus rostros, en un afán controlador-legitimador de identidad, validaban la concepción de la fotografía como análogo de la realidad. Rostro y representación del rostro eran análogos: el peso de la representación cabía en la imagen como referente, como prueba, verdad y orden, como una realidad no sólo legitimada socialmente, sino que legalizada institucionalmente.

En tal sentido, consideramos que la foto-carnet en su individualidad y descontextualizada del documento no actuó de fetiche para las comunidades indígenas, aunque coincidimos que sí se puede considerar ese fetichismo en el documento, como lo afir- ma Gordillo. El fetichismo de la fotografía implicaría transformar el referente en "cosa", en "sujeto", y no en su representación ${ }^{31}$. Ocurre en algunos contextos y producciones de la fotografía en la que ésta sí, ha asumido el carácter de fetiche, como lo es la fotografía mortuoria en determinadas sociedades, no en el caso que nos ocupa. Pero sí actuó como una representación de su identidad de gran valor documentaltestimonial, como lo ha sido en el arte occidental el retrato fotográfico. Dada la infrecuente posibilidad de acceder a tomas fotográficas propias, los grupos indígenas nunca se convirtieron en consumidores de fotografías, si bien desde la década del sesenta se advierte en algunas familias asentadas en áreas urbanas la toma de imágenes, son mínimas y afirman que "eso" - la foto - les era imposible pagar.

Un ejemplo singular de las afirmaciones aquí expresadas surgió en una instancia de recepción ocurrida en Colonia Aborigen, que plantea la relación de las huellas del rostro a la foto como prueba o evidencia física/factual de (auto)identificación: en una entrevista con imágenes, Raúl identificó a un amigo, Raimundo, en una fotografía de niño publicada en el libro de Grete Stern (Príamo, 2005) y obtenida por esa fotógrafa en 1964. Pero cuando le acercamos la imagen, Raimundo dudó en reconocerse. La situación fue compleja, emotiva, con gestos y silencios imposibles de traducir a palabras: fue recorriendo las páginas del libro, llegó a la imagen que su amigo había identificado, se detuvo unos instantes, dirigió su mirada a la que se encontraba en la página contigua y preguntó: ¿Quién será este tobita? Le respondimos si no reconocía a alguien y luego de un largo silencio volvió la mirada sobre "su imagen" y señalándola expresó: "...y si éste no soy yo, le pego en el palo...". Se levantó, se dirigió hacia al interior de su vivienda y regresó con un carnet de afiliación a un servicio social que tenía la foto más antigua que conservaba una foto-documento de su adolescencia - para compararla con la que se encontraba en el libro de Stern que era previa. Entonces dijo: “'Son parecidas no?”32 Este episodio refleja que la constatación de identidad se dio a partir de la comparación visual y operó en el plano de la imagen. Si bien luego Raimundo leyó el epígrafe de la foto que ahora (re)conocía, y a partir de la fecha en que fue tomada afirmó los datos de ubicación espacial en el contexto que él mismo refería. El elemento probatorio de la imagen, la foto-docu-

31. El fetichismo de la imagen transforma la foto en reliquia u objeto-fetiche, cumpliendo la función de mediación entre el objeto/sujeto y su representación. Mientras que en los actos de recepción de fotografía por parte de los indígenas chaqueños que hemos experimentado, la imagen de la foto-documento no tenía tal carácter, sino que claramente era asumida como una (re)presentación. La importancia del documento radica en el vínculo entre todos los sistemas de signos que el mismo sustenta, por un lado, y el valor que las comunidades indígenas le atribuyeron, por otro. Un ejemplo de la relación simbólica que implica el documento se puede observar en la película documental "Octubre pilagá. Relatos sobre el silencio" de Valeria Mapelman: una de las primeras escenas presenta a una pareja de ancianos pilagás sobrevivientes de la masacre de La Bomba (Formosa) de 1947 mostrando su documento, explicando cuándo se les había sacado la foto, cómo les obtuvieron las huellas digitales.

32. Entrevista a Raimundo Barrientos. Colonia Aborigen, 11 de mayo de 2007 


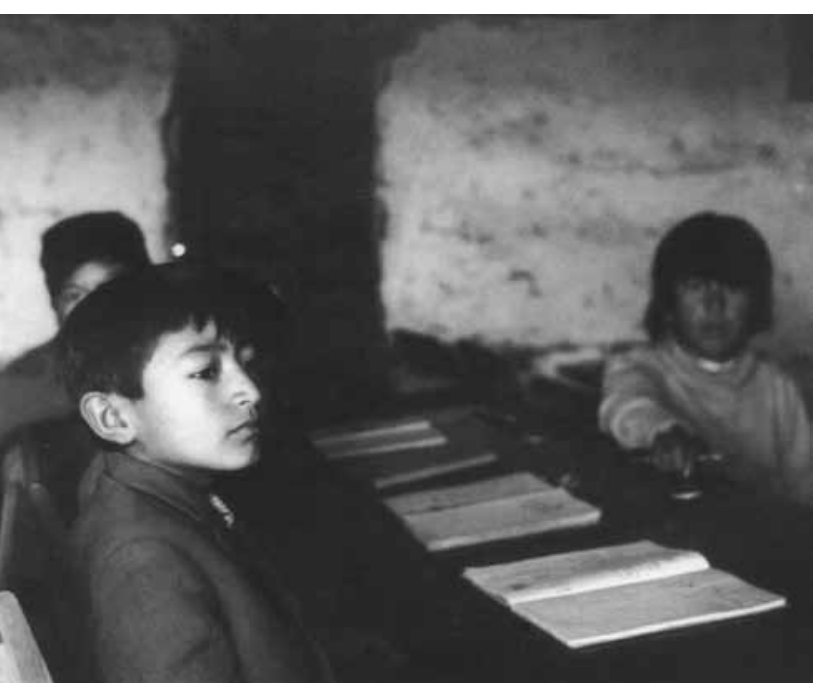

Imagen 3. Grete Stern. "Niño toba. Napalpí, 1964". Colección Matteo Goretti

Se trata del retrato de Raimundo que comparara con una foto-documento

mento como evidencia, es nuclear en este proceso de (auto)identificación ${ }^{33}$.

De tal forma, a lo largo de gran parte del siglo $\mathrm{XX}$ los indígenas chaqueños tuvieron en la fotodocumento el "espejo" donde siguieron mirando sus rostros y los de sus antepasados. Las otras imágenes que el Estado había obtenido, que circularon en publicaciones o informes de la administración estatal y que se preservan en diversas instituciones dependientes del Estado, no se transformaron en referentes identitarios, aunque constituyeron testimonios inapelables de "la realidad" indígena para el Estado y la cultura hegemónica que tuvo acceso a los mismos.

\section{Invisibilidades de la violencia}

En medio del proceso de sometimiento forzoso primero y de homogenización y normalización mediante el trabajo, la educación y la "inclusión" a la "nacionalidad argentina", un punto importante es la ausencia de imágenes de violencia militar o laboral: la mirada ofensiva que muchos textos periodísticos locales y nacionales enfatizaban sobre el indígena del Territorio Nacional del Chaco en las primeras décadas del siglo XX se silencia en la representación fotográfica. La lente construyó una idealización del proceso de apropiación del Estado Nacional de las tierras chaqueñas, donde la imagen se diferencia de aquellas obtenidas con los grupos indígenas apresados en las campañas al desierto sur. Aún cuando Niklison en su discurso escrito fue consciente de la violencia que la maquinaria productiva y las relaciones con el capitalismo implicaban sobre el indígena, la violencia visual se atenuaba en imágenes pacifistas y que de ningún modo contestaría lo denunciado.

Un hecho de particular relevancia es que hasta los hallazgos actuales en archivos se afirma, que desde el presupuesto de la invisibilidad, es la "Matanza o Sublevación de Napalpí" 34 ocurrida en la Reducción civil de Napalpí en 1924: constituido por un hito de la historia de los pueblos indígenas del Chaco, el sometimiento armado llevado a cabo por el gobierno del Territorio Nacional del Chaco implicó no solamente el envío de tropas policiales, sino también de un avión que sobrevoló la zona donde se encontraban tobas y mocovíes. Podríamos pensar que en la región no había fotógrafos ni cámaras en manos de particulares que pudieran haber registrado el conflicto o sus consecuencias - lo que es desmentido por fotografías urbanas y sociales de la misma época en localidades cercanas como Sáenz Peña y Quitilipi -, pero lo que resulta interesante en este proceso de invisibilidad es la presencia en el escenario de un personaje singular, que se erigió en testigo de los sucesos: nos referimos al antropólogo Robert Lehmann Nitsche, que arribó a Napalpí siendo director de la Sección Antropología del Museo de La Plata, indicando la prensa local su arribo a las pocas horas de producido el ataque por parte del Estado territoriano ${ }^{35}$. Si bien su presencia y accionar tenían una finalidad académica ${ }^{36}$, los mismos terminan en el cruce de visibilidades y ocultamientos de la Matanza de Napalpí, y por ello resulta importante considerar un conjunto de imágenes que

33. Esta actitud/experiencia es común en nuestras vidas: las fotos que nos sacaron de niños o jóvenes nos "congelan" en una edad, y para saber si nuestros hijos se parecen a nosotros, usualmente los comparamos con esas fotos del pasado, más que mirarnos como adultos.

34. Episodio desencadenado por factores de índole político-económico, explotación laboral y dominación estatal, de que eran objeto los pueblos indígenas en un contexto de difusión de ideas milenaristas. La protesta de los indígenas desencadenó una violenta represión el 19 de julio de 1924, con persecuciones a los sobrevivientes en los meses posteriores. Véase, entre otros, Cordeu y Siffredi (1971); Delrío y Lenton (2008).

35. Según el periódico opositor al gobierno territoriano y quien realizara las denuncias sobre la Matanza, el Heraldo del Norte, Lehmann Nitsche arribó a Napalpí junto a un asistente en el mismo día de la matanza y no le permitieron acercarse al lugar donde se produjo la misma, permaneciendo en la zona de la Administración de la Reducción, distante a unos $10 \mathrm{~km}$. del lugar de la matanza (Heraldo del Norte, 27 Junio 1925).

36. Cabe señalar que Lehmann Nitsche ocupa un lugar primordial en la visibilidad de los indígenas del Chaco argentino y en la historia de la antropología de la región, por haber sido el primer antropólogo que utilizó la imagen para estudios antropométricos de indígenas chaqueños. Dos publicaciones suyas son el ejemplo más claro del uso de la fotografía como complemento de sus mediciones antropométricas (Lehmann Nitsche, 1904 y 1907). En aquellas oportunidades las imágenes fueron obtenidas por el fotógrafo y taxidermista del Museo de La Plata Carlos Bruch. En 1924, la prensa hace referencia a un acompañante, pero no se ha podido identificar si era un fotógrafo. 


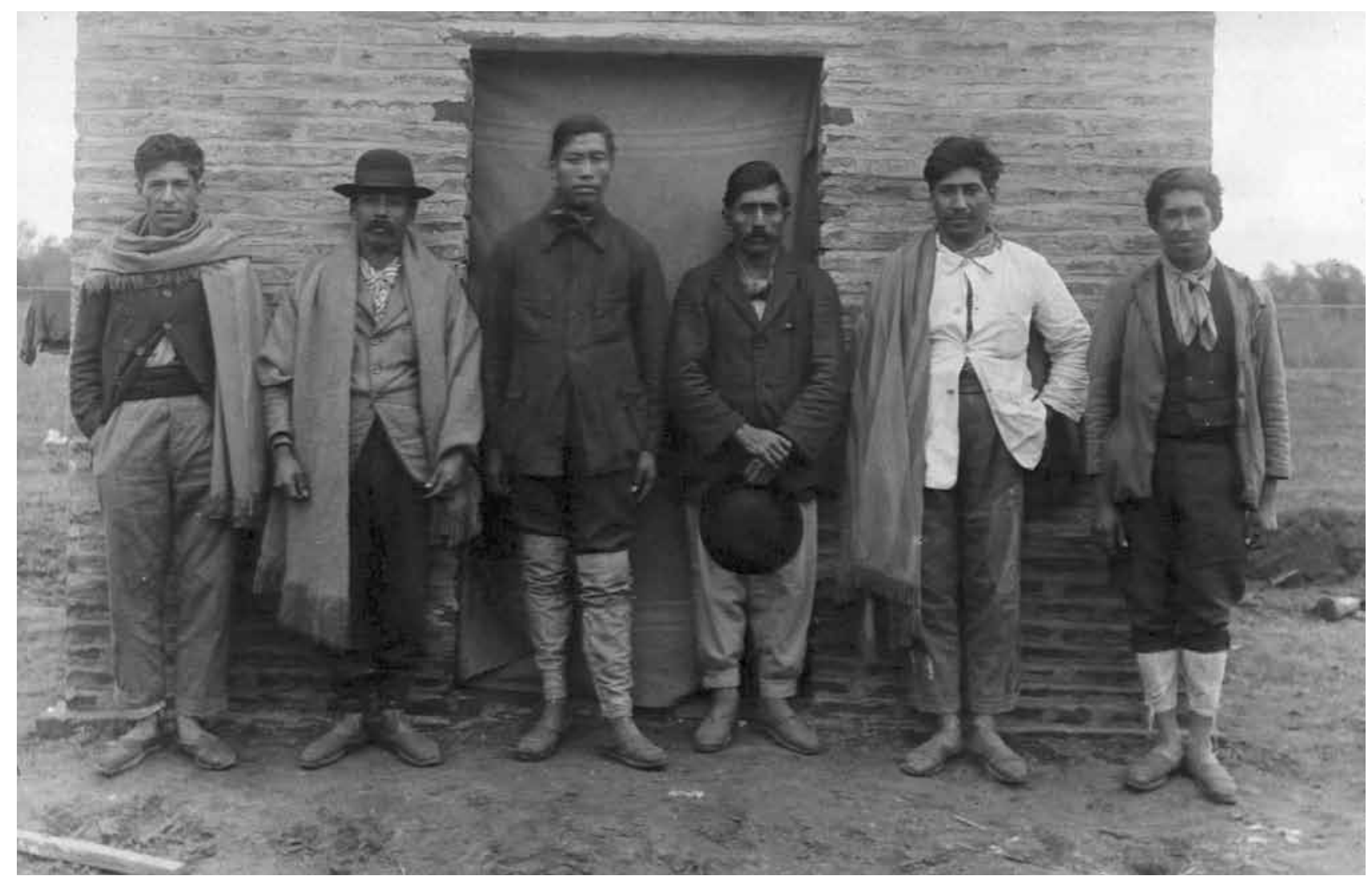

Imagen 4. Robert Lehmann Nitsche (atrib.). "Vilela, Napalpí”, 1924.

Ibero-Amerikanisches Institut (N-0070s56)

se les atribuyen: ellas son sobre catorce fotografías obtenidas presumiblemente por este antropólogo en esa visita - o por su "asistente" -, cuyos originales se hallan en su legado en el Instituto Iberoamericano de Berlín, y que hemos analizado en textos previos (Giordano, 2009), indagando en qué medida aquello que se pretendió ocultar o invisibilizar se hace presente en la imagen, a partir de ciertas "huellas" o "marcas" que miembros actuales de la comunidad indican/identifican. Ello se sustentaría en el principio de "invisibilidad de lo visual", a partir de una evaluación crítica de lo visible - ligado al referente - se indaga sobre lo invisible que ese mismo referente dispara, buscando desarticular la "realidad" fundada exclusivamente en el referente. Asimismo, esta lectura supone abordar el conflicto a partir del concepto de "desapariciones forzadas" (Grüner, 2002, p. 69) que hace "completar" la imagen con nuestras expectativas y con la mirada y la memoria de algunos descendientes de testigos de la matanza.

La primera impresión al observar estas catorce imágenes es la de una exposición fotográfica certera y amable de un grupo de indígenas frente a la cámara. Nada nos hace pensar en violencia, conflictividad ni muerte. Así, estas catorce fotos legitiman visualmente un ambiente apacible con indígenas "amigos" tobas y vilelas según las inscripciones, que posan ante la cámara y que poco indicaría el contexto de sangre en que concluyó la "sublevación" de Napalpí. Por lo tanto, estas imágenes son funcionales al discurso del Estado y parte de la prensa nacional y territoriana con respecto a los acontecimientos ocurridos en esa Reducción, que deslindaba responsabilidades $\mathrm{y}$ adjudicaban el enfrentamiento entre grupos tobas y mocovíes como causantes del conflicto, a la vez que negaban las muertes denunciadas.

La presencia de Lehmann Nitsche en el ámbito de la reducción de Napalpí había trascendido tanto en la prensa como en el ámbito oficial, y a pesar de su silenciamiento sobre lo ocurrido ${ }^{37}$, su nombre fue referido al tratarse los sucesos de Napalpí en una Comisión especial de la Cámara de Diputados (Lenton, 2005, p. 253).

La prensa opositora al gobierno territoriano y denunciante de la matanza, aseveraba que a Lehmann Nitsche y su asistente no se les permitió acercarse al escenario de la matanza, distante a unos diez kilómetros de la Administración de la Reducción. Si observamos las imágenes, nos encontramos con tomas que ponen en escena justamente los edificios de la Ad- 


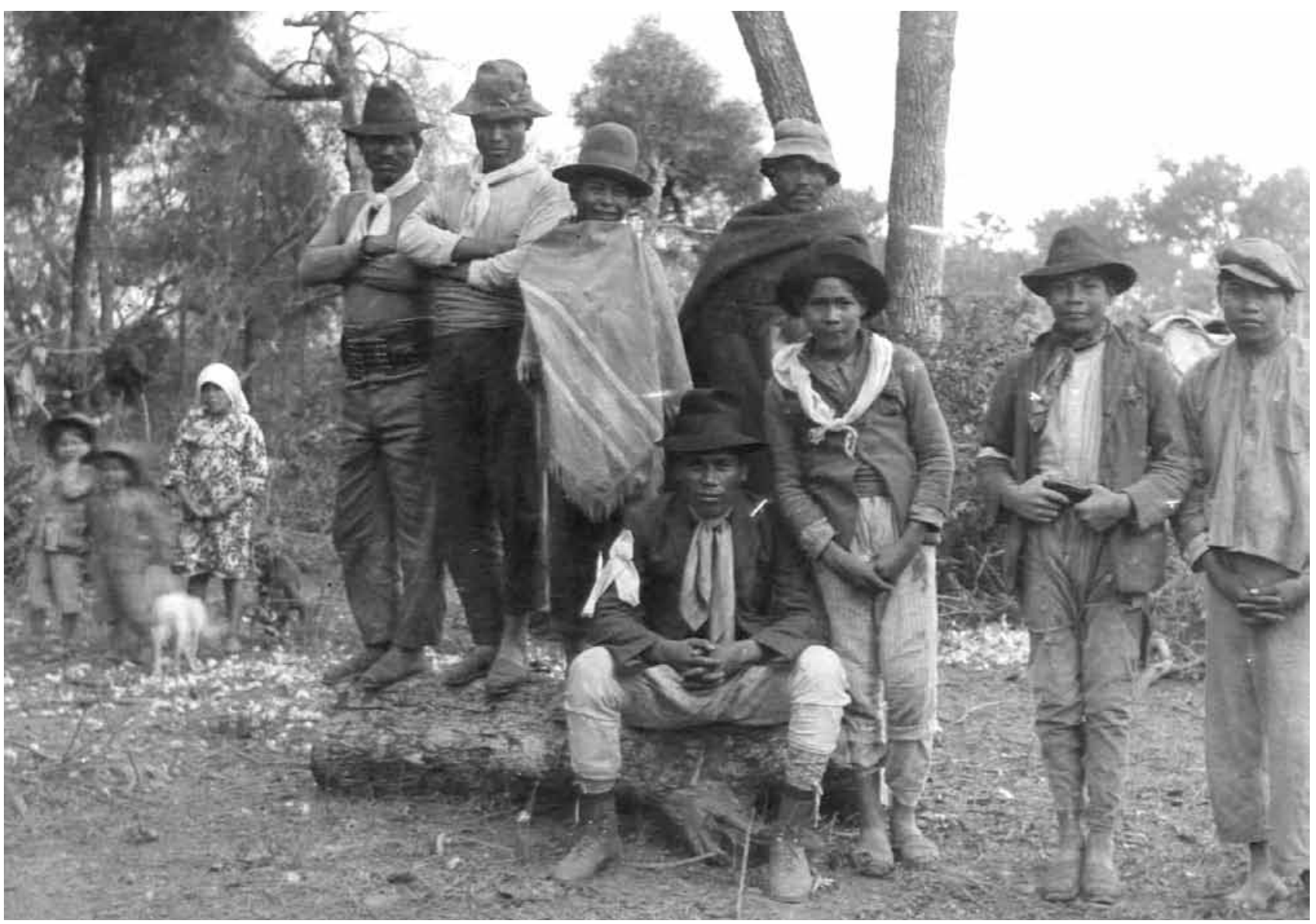

Imagen 5. Robert Lehmann Nitsche (atrib.). “Toba, Napalpí», 1924.

Ibero-Amerikanisches Institut, Berlin (N-0070s56)

ministración de Napalpí. Pero a la vez, descripciones de Lehmann en las fotos referencian a los retratados como tobas y vilelas ${ }^{38}$, este último grupo, reconocido por miembros de la comunidad como los "entregadores" del lugar donde se encontraban los indígenas "sublevados"39.

La condición de "amigos" a la cual aludía la imagen se convertía desde el referente en un índice en nuestra lectura. Pero Juan, al observar varias de las fotos en que los sujetos representados llevan un brazalete en sus brazos, señala que su abuela - quien había sobrevivido a la matanza - le había relatado que “... el brazalete era una forma de identificar los buenos de los malos. Durante la época de la matanza y la persecución posterior el brazalete identificaba a los buenos, los que estaban en la Reducción y el que no tenía esa señal era un salvaje. Mi abuela me lo contó hace mucho tiempo, yo dudaba, pero ahora veo esa marca acá en la imagen... y eso se vincula a la matanza" ${ }^{\prime 4}$. Esa "marca" asocia la imagen apacible y amistosa a uno de los hechos más sangrientos que viviera esa población, con la memoria familiar de Juan, pero a la vez "documenta" - en su lectura - la "entrega" de los vilelas, aún cuando las descripciones de Lehmann señalan tanto a tobas como vilelas como portadores del brazalete, como "indios buenos"

Sin duda esta aproximación a la imagen a partir de indicios secundarios se liga al tema que nos preocupa - la violencia del Estado en torno a la $\mathrm{Ma}-$ tanza de Napalpí - y refuerza la afirmación de Soulages de que "la fotografía no es ya una cita de la realidad, sino una historia puesta en escena" (Soulages,

38. Los vilelas estaban ubicados en la zona cercana a Resistencia, capital del Chaco. Al crearse la Reducción de Napalpí, su organizador, Enrique Lynch Arribálzaga, llevó un grupo de indígenas de esta etnia que se ubicaron en tierras de la administración de la Reducción.

39. Entrevista a Juan Chico. Resistencia, 26 de junio de 2009. Juan Chico es un intelectual toba, perteneciente a la comunidad de Colonia Aborigen (ex Reducción de Napalpí).

40. Entrevista a Juan Chico. Resistencia, 26 de junio de 2009

41 Juan establece así una relación entre los brazaletes y la delación, que podría no ser tan evidente, si pensáramos que podrían estar marcados como "indios buenos" desde antes de la matanza, o por no haberse plegado a la misma, sin que sean delatores. Sin embargo, la presencia en las imágenes de los mismos sujetos que portaban brazalete en la imagen del avión que trataremos más adelante, podría reafirmar las palabras de Juan. 


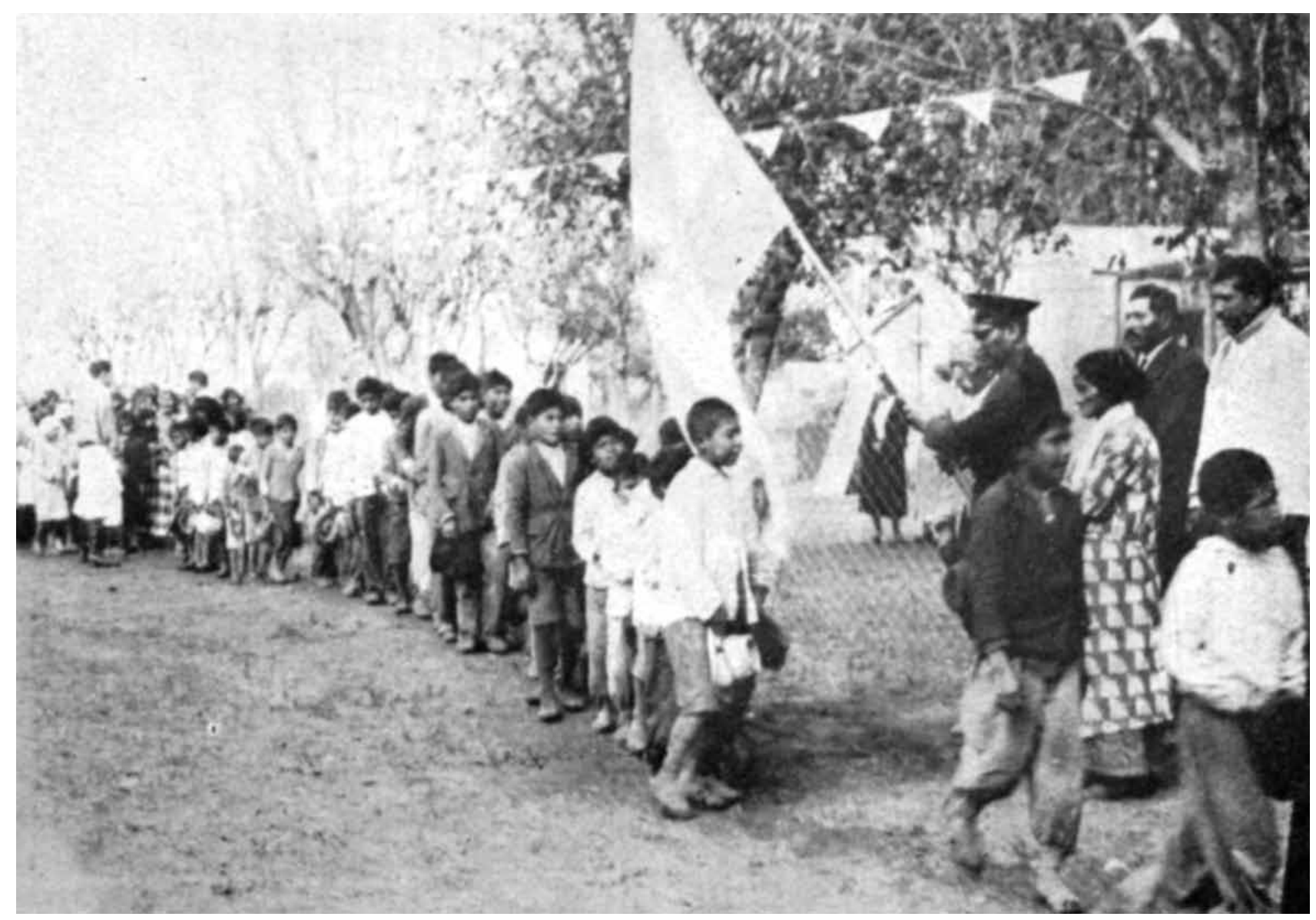

Imagen 6. Comisión Honoraria de Reducciones de Indios. Publicación N4. Juramento a la bandera, 1936 Al lado del abanderado se observa a la Cacica Dominga

2005, 85). La imagen fotográfica hace "desaparecer forzosamente" un conflicto, si nos remitimos solamente a "lo fotografiado". Pero si nos atenemos a "lo fotografiable" este corpus nos remite a una historia más compleja que la memoria de la comunidad complementa. Asimismo, una sola foto que aún no hemos considerado del conjunto de las catorce de Lehmann Nitsche, completa otros aspectos de la matanza y de la memoria comunitaria de Napalpí. Se trata de una imagen en que se presenta un avión en el que se distingue "2 Chaco" con su piloto en la cabina, un grupo de hombres delante del avión - razón por la cual no se distingue toda la inscripción que lleva el mismo -, varios de ellos con fusiles Winchester en la mano, un policía del Territorio y en un segundo plano un pequeño grupo de indígenas, algunos de los que aparecen en el resto de las imágenes. La foto tiene una inscripción en el reverso - presumiblemente incorporada por Lehmann, al igual que las inscripciones de algunas otras fotos -, que dice: "Flugzeug gegen den Indianeraufstand" ("Avión contra levantamiento indígena"), ${ }^{42}$ lo que sitúa claramente esta imagen en el contexto de la Matanza. Pero a la vez lo hace presente a Lehmann en el escenario, por encontrarse fotografiado entre el grupo que rodea el avión.

La prensa opositora al gobierno de la época de la matanza ${ }^{43}$ y la memoria de los sobrevivientes y sus descendientes han referido a la presencia de un avión de Aerochaco 2 que sobrevoló la zona en la que se encontraban tobas y mocovíes a espera de promesas de resolución del conflicto planteado al gobierno territoriano. La prensa oficialista decía que el día 18 de julio se había enviado un avión para supervisar el "campamento de los alzados", mientras el periodismo opositor señaló que cuando los cuadros de gendarmería y policía ya estaban desplegados para el ataque el aeroplano tripulado por el sargento Esquivel sobrevoló el campamento indígena, y que siguió haciéndolo "siniestramente" tras la matanza para confirmar a la policía que no había peligro (Heraldo del Norte, 27/06/1925).

Sobre la presencia del avión y lo que esta imagen significa para Napalpí nos decía Juan: "Hay dos versiones: en nuestra comunidad unos dicen que el avión

42. La traducción es nuestra.

43. Nos referimos al ya citado El Heraldo Chaqueño, luego denominado Heraldo del Norte, que fue el principal periódico local que marcó un discurso diferencial sobre lo ocurrido en Napalpí, y editó un número especial sobre los sucesos y su tratamiento discursivo por la prensa en 1925. 
pasó días previos de la matanza para hacer reconocimiento y que ese día sobrevoló y el ruido hizo que la gente saliera porque estaba expectante de la promesa del gobernador. Otra versión, que viene de los vilelas, dice que el avión tiró caramelos y que eso hizo que la gente se juntara en un lugar y favoreció el ataque de la policía. A mi este avión de la foto me impresiona, pero me interroga si la foto es antes o después de la matanza" 44 .

A ello completaba David diciendo: "Para mi el avión es la imagen de la victoria. Parece decir «hemos terminado el trabajo", ese es el mensaje. Para mí es lo después, no lo antes". ${ }^{45}$

La foto del avión abre también la discusión sobre el tema de la "nacionalidad" y el rol del Estado que varios receptores señalaron en una instancia expositiva de estas imágenes en la comunidad ${ }^{46}$. Entre las imágenes que se presentaron, además de las de Lehmann Nitsche, se encontraban algunas de las analizadas previamente que correspondían a los inspectores de la Comisión Honoraria de Reducciones de Indios, entre ellas un par de imágenes donde la Cacica Dominga observaba el Juramento a la bandera por parte de hombres, mujeres y niños de Napalpí. La bandera presente en el avión involucrado en la matanza, y la repetición del símbolo en estas imágenes, se convirtió en la marca de reflexión de jóvenes tobas. Carlos señalaba: “... eso es lo que yo no entiendo... primero nos hacen jurar lealtad a la bandera (señalando la imagen del juramento a la bandera) y después nos matan (señalando el avión) ${ }^{47}$. Mientras Mario, que había reconocido a un abuelo de su esposa en los retratos de vilelas tomados por Lehmann Nitsche, apuntaba: "A mí me impresiona ver la bandera en el avión, y verla en esta otra foto (señalando el juramento). No entiendo, éramos parte de la Argentina, pero el mismo país nos mandó el avión ${ }^{48}$.

\section{Epílogo}

La producción diferencial y los usos de la imagen operada desde los agentes del Estado nacional y territoriano derivaron en "vidas" distintas de la imagen fotográfica. Aquellas que "documentaban" el sometimiento armado, que pretendían "testificar" modos de vida y costumbres retratando a grupos indígenas, constituyeron material de archivo y, por ello fueron durante décadas totalmente desconocidas por los sujetos/objetos de representación y sus descendientes ${ }^{49}$.

Por el contrario, las que integran diversos documentos de identificación desde una estrategia asociada a la fisognomía gravitada por una fuerte impronta de ideas raciales que rehusaban a considerar los contextos etnográficos, son las imágenes que se introdujeron en el contexto personal e íntimo de los indígenas chaqueños. Fueron también estas las que supusieron la primera relación de conservación de la imagen desde las comunidades. La potencia de la representación fotográfica asumió, a partir de la foto-carnet o foto-documento un status de constatación: "ése era yo cuando era chico", "ésta es la foto más vieja que tengo, mirá", fueron algunas de las reflexiones sobre las fotos que conservaban, sin preguntarse sobre el contexto de producción de las mismas. Sin embargo, reflexionaban acerca de aquellas que nosotros les acercábamos: "son de la conquista, mirá, esos indios tienen uniformes militares", o "qué raro verla a la Cacica Dominga en esa foto del juramento a la bandera". La foto-carnet era asumida como sinónimo de su identidad, pero también como si "propio", lo que conservaban de sus familiares o de ellos mismos: no reflexionaron sobre lo "actuado", ni lo probatorio o el status normalizador que nosotros leíamos en esas imágenes.

La fotografía define un espacio que no solo nos permite discutir las cuestiones de representación y representatividad, las estrategias de homogeneización y normalización visual y social, de cambio cultural forzado, de discriminación y determinismo racial, sino que a estas cuestiones subyace la invisibilidad/ visibilidad, la memoria y el olvido como estrategias de construcción de lo visual.

Las narrativas visuales procedentes de agentesrepresentantes del Estado ponen en evidencia que no existieron estrategias comunes en los modos de construir lo social desde lo visual, pero que $\sin$ embargo, estos paquetes visuales se transformaron en argumento de construcción de nacionalidad y de identidad "desde arriba". La segmentación de lo social debía encontrar relatos visuales unificadores de una "comunidad imaginada": visualidades que evitaran la erosión de identidades múltiples y que pusieran en evidencia el rol preponderante del Estado

44. Entrevista a Juan Chico. Resistencia, 26 de junio de 2009.

45. Entrevista a David García. Resistencia, 26 de junio de 2009

46. Entre mayo y junio de 2010 se realizó, por demanda de varios referentes comunitarios a quienes habíamos entrevistado anteriormente, una presentación de las imágenes en el salón de la Asociación Comunitaria de Colonia Aborigen (ex Reducción de Napalpí).

47. Entrevista a Carlos Samuel Ortega. Colonia Aborigen, 4 de mayo de 2010.

48. Entrevista a Mario Paz. Colonia Aborigen, 4 de mayo de 2010.

49. A partir de un trabajo de investigación dialógica con las comunidades indígenas que hemos realizado entre 2005 y 2010 con una selección de fotografías históricas, estas imágenes han sido conocidas por algunas de ellas. 
en la construcción de identidades y visualidades, y en encontrar un "hogar" para la historia del indígena chaqueño en la historia argentina, que invisibiliza la violencia en la virtual "fundación" del Chaco.

\section{Referencias}

ALEXANDER, Abel; CUARTEROLO, Miguel Ángel; TOYOS, Sergio. Soldados: 1848-1927. Buenos Aires: Editorial Edivern, 2001.

ALTAMIRANO, Carlos; SARLO, Beatriz. La Argentina del Centenario: campo intelectual, vida literaria y temas ideológicos. In: Ensayos argentinos: de Sarmiento a la vanguardia. Buenos Aires: CEAL, 1983.

ALVARADO, Margarita. Pose y montaje en la fotografía mapuche: retrato fotográfico, representación e identidad. In: ALVARADO, Margarita; MEGE, Pedro; BÁEZ, Christian (Eds.). Mapuche: fotografía siglos XIX y XX - construcción y montaje de un imaginario. Santiago: Pehuén Editores, 2001. p. 13-28.

AMIGO, Roberto. Imágenes de la historia en el Centenario: nacionalismo e hispanidad. In: GUTMAN, Margarita; REESE, Thomas (Eds.). Buenos Aires 1910: el imaginario para una gran capital. Buenos Aires: Eudeba, 1999. p. 171-195.

ANDERMANN, Jens. The optic of the State: visuality and power in Argentina and Brazil. Pittsburgh: University of Pittsburgh, 2007.

ARNHEIM, Rudolf. El poder del centro: estudio sobre la composición en las artes visuales. Madrid: Akal, 2001.

BAUDRILLARD, Jean. Simulacra and simulations. In: POSTER, Mark (Ed.). Jean Baudrillard: selected writings. Stanford: Stanford University Press, 1998. p. 166-184.

BECK, Hugo. Las relaciones entre blancos e indios en los Territorios Nacionales de Chaco y Formosa: 1885-1950. Cuaderno de Geohistoria Regional, Resistencia: IIGHICONICET, n. 29, 1994.

BREA, José Luis. Los estudios visuales: por una epistemología política de la visualidad. In: BREA, José Luis (Ed.). Estudios visuales: la epistemología de la visualidad en la era de la globalización. Madrid: Akal, 2005

BRIONES, Claudia; LENTON, Diana. Debates parlamentarios y nación: la construcción discursiva de la inclusión/exclusión del indígena. In: ACTAS DE LINGÜÍSTICA ABORIGEN, 3. Buenos Aires: Instituto de Lingüística, UNA, 1997.

BURKE, Peter. Visto y no visto: el uso de la imagen como documento histórico. Barcelona: Editorial Crítica, 2001. COMISIÓN HONORARIA DE REDUCCIONES DE INDÍGENAS. Publicación n. 4. Buenos Aires: La Prensa Médica Argentina, 1936.

COURDEU, Edgardo; SIFFREDI, Alejandra. De la algarroba al algodón: movimientos milenaristas en el Chaco argentino. Buenos Aires: Juárez Editor, 1971.

DELRIO, Walter; LENTON, Diana. Negaciones y reconocimientos del genocidio en la política indígena del
Estado argentino. In: JORNADAS DE HISTORIA DE LA PATAGONIA, 3. Bariloche, 2008.

DEWERPE, Alain. La "stratégie" chez Pierre Bourdieu. Enquêt: Anthropologie, histoire, sociologie, Marseille: Éditions Parenthèses, n. 3, p. 191-208, 1996.

DOMINGUEZ, Marcelo; GOLLUSCIO, Lucía; GUTIÉRREZ, Analía. Los vilelas del Chaco: desestructuración cultural, invisibilización y estrategias identitarias. Indiana, Berlín: Ibero-Amerikanisches Institut, v. 23, p. 199-226, 2006.

DUBOIS, Philippe. El acto fotográfico y otros ensayos. Buenos Aires: La Marca Editora, 2008.

EDWARDS, Elizabeth. Anthropology E photography: 18691920. London: Yale University Press, 1992.

ESCOLAR, Diego. Los dones étnicos de la Nación: identidades huarpe y modos de producción de soberanía en la Argentina. Buenos Aires: Prometeo, 2007.

FOUCAULT, Michel. Microfísica del poder. Madrid: Ediciones La Piqueta, 1993.

GIORDANO, Mariana. Discurso e imagen sobre el indígena chaqueño. La Plata: Al Margen, 2004a.

GIORDANO, Mariana. De Boggiani a Métraux: ciencia antropológica y fotografía en el Gran Chaco. Revista Chilena de Antropología visual, Santiago de Chile: Universidad Academia de Humanismo Cristiano, v. 4, 2004b. Disponible en: <http://www.antropologiavisual. cl/americanistas >. Acceso: 3 ene. 2009.

GIORDANO, Mariana. Indígenas y fotografía anglicana: una mirada al grupo lengua de Markthalawaiya. Suplemento Antropológico, Asunción: Ceaduc/Universidad Católica de Asunción, v. XLI, n. 2, 2006.

GIORDANO, Mariana. Estética y ética de una imagen del otro. Aisthesis, Santiago: Pontificia Universidad Católica, n. 46, p. 65-82, 2009.

GIORDANO, Mariana. Las comunidades indígenas del Chaco frente a los acervos fotográficos de sus antepasados: experiencias de (re)encuentro. In: DA SILVA CATELA, Ludmila; GIORDANO, Mariana; JELIN, Elizabeth (Eds.). Fotografía e identidad: captura por la cámara, devolución por la memoria. Buenos Aires: Nueva Trilce, 2010. p. 21-58.

JELIN, Elizabeth; MÉNDEZ, Patricia. Justificando un proyecto: textos y fotografías de los frailes de Propaganda Fide sobre los indios chaqueños. In: CONGRESO INTERNACIONAL DE TEORÍA E HISTORIA DE LAS ARTES, 1. Buenos Aires: CAIA, 2001.

GORDILLO, Gastón. En el Gran Chaco: antropologías y historias. Buenos Aires: Prometeo, 2006. 
GORDILLO, Gastón. Landscapes of devils: tensions of place and memory in the Argentinean Chaco. Durham: Duke University Press, 2004.

GRUNER, Eduardo. El sitio de la mirada. Buenos Aires: Norma, 2002.

IÑIGO CARRERA, Nicolás. Campañas militares y clase obrera: Chaco, 1870-1930. Buenos Aires: CEAL, 1984.

LAGOS, Marcelo (Ed.). Estudio preliminar. In: NIKLISON, José Elías. Investigación sobre los indios matacos trabajadores (1917). Jujuy: UNJU, 1989.

LEHMANN NITSCHE, Robert. Etudes anthropologiques sur les indiens takshik du Chaco Argentin. Revista del Museo de La Plata. La Plata, v. 11, p. 263-313, 1904.

LEHMANN NITSCHE, Robert. Estudios antropométricos sobre chiriguanos, chorotes, matacos y tobas. Anales del Museo de La Plata, Buenos Aires: Coni, t. I, segunda serie, p. 7-190, 1907.

LENTON, Diana. De centauros a protegidos: la construcción del sujeto de la política indigenista argentina a través de los debates parlamentarios. Tesis (Doctorado en Ciencias Antropológicas) - Universidad de Buenos Aires, Buenos Aires, 2005. Inédito.

LOIS, Carla. La invención del desierto chaqueño: una aproximación a las formas de apropiación simbólica de los Territorios del Chaco en los tiempos de formación y consolidación del Estado Nación Argentino. Scripta Nova: Revista Electrónica de Geografía y Ciencias Sociales, Barcelona, n. 38, 1999.

MILLER, Elmer Los tobas argentinos: armonía y disonancia de una sociedad. México: Siglo XXI, 1979.

MITCHELL, W. J. T. Mostrando el ver: una crítica de la cultura visual. Estudios Visuales, Madrid, v. 1, p. 17-40, 2003.

MUÑOZ, Miguel Ángel Muñoz. El arte nacional: un modelo para armar. In: El arte entre lo público y lo privado Buenos Aires: CAIA, 1995. p. 154-165.

NIKLISON, José Elías. Los indígenas del Norte en la Argentina - apuntes de actualidad. La Revista del Mundo, Buenos Aires, abr. 1919.

PENHOS, Marta. Frente y perfil: fotografía y prácticas antropológicas y criminológicas en Argentina a fines del siglo XIX y principios del XX. In: PENHOS, Marta et al. Arte y antropología en la Argentina. Buenos Aires: Fundación Telefónica/Fundación Espigas/FIAAR, 2005. p. 16-64. PRÍAMO, Luis (Cur). Aborígenes del Gran Chaco: fotografías de Grete Stern 1958-1964. Buenos Aires: Fundación Antorchas/Fundación CEPPA, 2005.

QUIJANO, Anibal. Colonialidad del poder, eurocentrismo y América Latina. In: PAJUELO, R.; SANDOVAL, P. (Eds.). Globalización y diversidad cultural: una mirada desde América Latina. Lima: Instituto de Estudios Peruanos, 2004. p. 228-281.

REYERO, Alejandra. Ver en fotos ¿rever en la memoria? Límites y alcances de la fotografía en la construcción de memoria e identidad de una comunidad toba". In: DA SILVA CATELA, Ludmila; GIORDANO, Mariana; JELIN, Elizabeth (Eds.). Fotografía e identidad: captura por la cámara, devolución por la memoria. Buenos Aires: Nueva Trilce, 2010. p. 59-83.

REYERO, Alejandra. La cara te dice todo. Revista Chilena de Antropología Visual, v. 14, 2009. Disponible en: <http:// www.antropologiavisual.cl>. Acceso en: 15 jul. 2010.

SANTOS, Milton. Técnica, espaço, tempo: globalização e meio técnico-cientifico informacional. São Paulo: Hucitec, 1997.

SCARZANELLA, Eugenia. Ni gringos ni indios: inmigración, criminalidad y racismo en la Argentina 1890-1940. Bernal: Universidad Nacional de Quilmes, 2003.

SEGATO, Rita. La nación y sus otros: raza, etnicidad y diversidad religiosa en tiempos de políticas de la identidad. Buenos Aires: Prometeo, 2007.

SONTAG, Susan. Sobre la fotografía. Buenos Aires: Sudamericana, 2006.

SOULAGES, François. Estética de la fotografía. Buenos Aires: La Marca, 2005.

TAGG, John. El peso de la representación. Barcelona: Gustavo Gilli, 2005.

TRINCHERO, Héctor. Los dominios del demonio: civilización y barbarie en las fronteras de la Nación - El Chaco Central. Buenos Aires: Eudeba, 2000.

ZEBALLOS, Estanislao. Soñando con los indios del Chaco. Buenos Aires: Talleres Gráficos Rosso, 1918. 


\title{
Submeter pelas armas, vigiar pela câmara: Estado e visualidade no Chaco indígena
}

\section{Resumo}

Os modos de construir o visual no Chaco argentino seguem diferentes estratégias sustentadas pela microfísica do poder. Se bem que elas não emanam somente do Estado nacional, foi a partir do planejamento das ações e as representações do Estado, que emergiu uma construção da tensão, controle e coerção sobre as comunidades indígenas. Pretendemos analisar a maneira em que o visual se apresenta como uma experiência que articula a visão com as prácticas culturais, sociais e individuais. A partir de uma análise das diversas abordagens de (re)presentação das fotografias do indígena do Chaco, investigamos sobre seu papel como prova, verdade e ordem no processo de submissão, vigilância e normalização; o que demonstra acomplexidade do entramado do poder e visualidade, que em diferentes estratos e usos se manifestaram historicamente.

Palavras-chave: Estado; o visual; fotografias; Chaco indígena; submissão.

\section{Submit through guns, surveil through cameras: State and visuality in the indigenous Chaco}

\begin{abstract}
The differents ways to build the visuality in the Argentine Chaco followed strategies sustained by microphysics of power. Although they do not emanate only from the National State, the actions and representations planning from that, influenced to the construction of the power, control and coercion on indigenous groups. We intend to analyze how the visuality experience is presented in the articulation of cultural, social and individual politics. From an review of several approaches aimed indigenous of Chaco, we ask about their role as evidence, truth and order in the process of submitting, vigilance and standardization. So, we show up the complexity of the retationship between power and visuality, that were expressed historically in different layers / strata and uses / circulation.
\end{abstract}

Key words: State; visuality; photography; Chaco indigenous; submitting.

Data de recebimento do artigo: 24/10/2010

Data de aprovação do artigo: 29/07/2011 